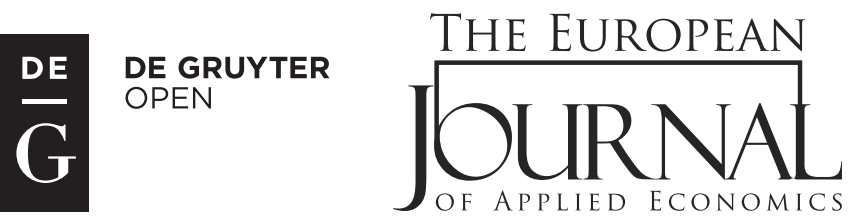

EJAE 2017, 14(2): 70-75

ISSN 2406-2588

UDK: $378.147:: 338.48(497.11)$

37.033-057.875(497.11)

DOI: $10.5937 /$ ejae14-15571

Original paper/Originalni naučni rad

\title{
TALENT DEVELOPMENT AND EDUCATION IN TOURISM
}

\section{Slobodan Unković}

Singidunum University,

Belgrade, Serbia

\begin{abstract}
:
Tourism, both international and domestic, has become one of the most important factors of social and economic development throughout the world. For that reason, quality of education in the field of tourism and strategies for talent development should be considered matters of utmost importance. In this paper, I present my views on primary, secondary and higher education in the field of tourism, as well as on education of tourist guides. I also present a brief case study of Singidunum University, as an example of good practice in higher education in the field of tourism.
\end{abstract}

\section{Keywords:}

education,

tourism and hospitality,

higher education,

secondary education, professional education.

\section{PRIMARY EDUCATION IN TOURISM}

Education for the field of tourism is a part of the comprehensive education system of a country. Consequently, there are some common elements that apply to all students. This is primarily the case with eight-or nine-year primary education. It is important that measures for stimulating and preparing talent for future professional orientation should be taken at this level of education. This is particularly important for countries and tourist destinations whose development is largely dependent on tourism (Hsu, Xiao \& Chen, 2017). This means that at this stage of education young people, and young talent in particular, should be prepared for inclusion in various activities that successful development of tourism in those tourist locations and/or countries depends on. The quality of tourism education at higher educational levels largely depends on the level of knowledge acquired during this first level of education (Unković, 1990).

It is vital that special importance in the curricula of this educational level, in addition to standard subjects, be attached to the learning of international languages as well as elementary knowledge in the field of Information Science (Sheldon, Fesenmaier \& Tribe, 2011).

\section{SECONDARY EDUCATION IN TOURISM}

The three-or four-year secondary education is of particular importance for tourism. The size of the network of schools specializing in Tourism and Hospitality depends to a great extent on the importance of tourism for the economic development of a given country or a tourist location (Benckendorff 
\& Zehrer, 2015). The characteristics of tourism as an economic activity, particularly with respect to the provision of accommodation, food and other areas that cater for the needs of tourists influence the demand for such job profiles.

These job profiles include professions such as waiters, bartenders, chefs, pastry chefs, receptionists, masseurs in wellness centers and other professions learnt at this level of education (Inui, Wheeler, \& Lankford, 2006). The quality of services in hotels, restaurants, and various organizations that provide services to tourists, depends to a large extent on the quality of these professionals. These professionals are educated in specialized secondary schools. Their curriculum needs to find the right balance between general knowledge and applied practice in school workshops, school-owned hotels and restaurants and numerous organizations in this field with which a permanent cooperation has been established. It is important for professionals at this level of education to constantly improve their knowledge and skills through the organization of brief innovation programmes. In this respect, hotel and restaurant chains have been particularly successful. This is a good opportunity for both selection and encouragement of talent to acquire new knowledge, as well as preparation for continued education at higher levels. Tourism and educational policies need to stimulate young people, especially the talented ones, to choose to learn in these educational institutions with the option of continuing and studying at a higher level (Belhassen \& Caton, 2011). It is important that the curricula of these specialized secondary schools, in addition to general educational and professional subjects, should emphasise the learning of global languages at higher levels, as well as application of modern information technologies.

\section{HIGHER EDUCATION IN TOURISM}

The higher education system for tourism purposes plays an important role. There is a wide network of quality vocational higher education schools and academic university schools in the field of tourism. Most of them are related to hotel management or hospitality management (Barrows \& Bosselman, 1999). The area of higher education, and by extension higher education in the field of tourism, is based on the application of the so-called Bologna Declaration signed by all European countries (Munar, 2007). Pursuant to this document, all European countries are attempting to apply the principles laid down as the basis for accreditation of curricula and study programmes, as well as relevant higher education institutions that implement these programmes. A monitoring system has also been implemented at the European level, which regulates the implementation of what constitutes the basis for the application of this system in the organization of higher education. National legislation specifies the institutions responsible for the accreditation of curricula of vocational higher education schools, faculties and universities. From the standpoint of conditions required for the successful development of tourism in a given country and the creation of an appropriate network of higher education institutions, one should bear in mind the multidisciplinary nature of tourism as a business activity (Dredge \& Schott, 2013). This means that there is a demand for higher-educated professionals from various scientific fields and disciplines. The demand for professionals in the fields of Economics and Management is dominant, since there is a large number of companies and organizations that participate in the provision of services to tourists, whilst applying the principles of rational economic business operation and answering to market demands. However, this also means that the following higher-educated professionals are also needed: ecologists, geographers and spatial planners, psychologists, lawyers, sociologists, financial experts, marketing and public relations specialists, different profiles of technical intelligence, especially architects, electrical engineers, information technology specialists and other profiles of experts (Sheldon \& Hsu, 2015). The majority of such professionals at the higher education level are educated 
at the vocational higher education schools, faculties and universities in the fields mentioned. Those interested in the field of tourism may opt for specialization in the form of one-year or two-year Master's programmes or specialist studies in educational institutions with accredited programmes for the field of tourism and hotel management at this level (60 or 120 ECTS).

This indicates that they have previously completed either regular vocational or academic studies with 180 or 240 ECTS. As already mentioned, in most countries the education of tourism professionals at the vocational and academic level is implemented through special institutions which are focused on Economics and Management (Bachelor and MBA Graduate Studies).

The three-year PhD studies (180 ECTS), with previously acquired 300 ECTS during academic university studies, are primarily organized as multi-disciplinary, with an emphasis on Economics, Management, Methodology of Scientific Research and Information Science. These studies can only be implemented by university institutions which satisfy the rigorous criteria for the quality of teachers with respect to their results in the field of science.

At the higher education level, whether vocational or academic, the talent selection system is considered vital for the successful development of tourism at the country level, tourist destinations and companies in the tourism industry (Law \& Chon, 2007). It is necessary to establish a permanent system of talent selection through educational and tourism policy. This should be realized through the granting of scholarships and various types of awards for the best participants at various international and national academic and research conferences. Talent is important not only for the successful development of the tourism industry, but also for effective measures for advancing the development of tourism at the country level and priority tourist destinations.

The quality of this level of professional education for the purposes of tourism, from undergraduate studies to the acquirement of a $\mathrm{PhD}$, largely depends on the institutions that make decisions on the accreditation of study programmes, educational institutions, as well as constant quality control. This applies to both state and private higher education institutions (Prebežac, Schott \& Sheldon, 2014).

\section{EDUCATION OF TOURIST GUIDES}

The education of tourist guides is of special significance for the successful development of tourism in a particular country. The implementation of programmes for the issuance of tourist guide licenses differs from country to country (Zagonari, 2009). Considering the importance of the quality of tourist guides, it is suggested that the competent state authority for tourism in a country cooperate with higher education institutions in the field of tourism on the preparation of a programme for tourist guides. Such programmes can be implemented within the competent state authority for tourism or the National Tourism Organization in cooperation with higher education and scientific institutions. There is no need to establish dedicated higher education institutions for the education of these profiles. The programme should last about six months and be based on a multidisciplinary principle. The final exam should be taken over several days and be realized in specific tourist destinations in the country or abroad. The admission exam for candidates with previously obtained degrees from higher education institutions should facilitate the selection of the best candidates with flawless knowledge of the global languages for which they will be licensed. This license should be issued by the competent national authority for tourism. At the same time, it is necessary to implement rigorous control of the persons performing the tasks of a tourist guide. The practice in some countries indicates that these jobs are often performed by people without a tourist guide license and the abilities required to do them. 


\section{THE CASE STUDY OF SINGIDUNUM UNIVERSITY}

The Singidunum University in Belgrade was established 18 years ago as a private university by renowned academics and professors of state universities. The university began with the establishment of the Faculty of Financial Management and Insurance with 65 students 18 years ago.

In 2017, Singidunum University enrolls approximately 9,000 students attending academic four-year studies, Master's studies and $\mathrm{PhD}$ studies. It covers the following scientific fields: social sciences and humanities, engineering and natural and mathematical sciences. This was a pre-condition for obtaining the accreditation for research and academic university education. The University includes the following faculties: the Faculty of Business, the Faculty of Tourism and Hospitality Management, the Faculty of Technical Sciences, which encompasses Electrical Engineering, Engineering Management and Software Engineering, Faculty of Informatics and Computing, the Faculty of Physical Culture and Sports Management, and the Faculty of Media and Communications, which comprises Psychology and the Faculty of Applied Ecology. Teaching activities are carried out in Belgrade, as the University centre, as well as three other cities in Serbia - Novi Sad, Niš and Valjevo. The University owns high-quality teaching premises about $15,000 \mathrm{~m}^{2}$ and the latest IT equipment and other resources needed for quality teaching at all levels. Thus far, 20 programmes of undergraduate academic studies (240 ECTS), 10 Master's study programmes (60 ECTS) and $6 \mathrm{PhD}$ programmes (180 ECTS) have been accredited. There are over 350 teachers and associates in permanent employment, as well as a number of domestic and foreign visiting professors. The University has developed partnerships with over 50 foreign universities from Europe, USA, China and other parts of the world. It is also a member of a number of well-known research and professional associations, among which UNWTO is particularly prominent. Cooperation with the business sector and relevant state institutions and chambers of commerce is a regular practice at this university. There are about 500 active agreements with companies and institutions where a part of the teaching process and professional practice is implemented, which is an integral part of the realization of the curriculum. At all levels of education, lectures are held in Serbian and English.

The Faculty of Tourism and Hospitality Management has been a part of Singidunum University since 2003. Each year, 300 students are enrolled in undergraduate four-year academic studies (240 ECTS), 50 students in the Master's level programme Tourism Management (60 ECTS) and 5 students in the $\mathrm{PhD}$ programme Tourism Management (180 ECTS). These study programmes were accredited by the competent national institution, and the undergraduate and Master's studies have also been accredited by the UNWTO TEdQual Certificate Programme for a number of years. On all programmes, lectures are held in the native Serbian as well as English language. Students come from all parts of Serbia, as well as countries of the former Yugoslavia. There is also a considerable number of students from other countries at the Master's and doctoral level. It is important to note that for many years University organized an undergraduate programme in English, in cooperation with the Krems University of Austria. In addition, a joint MBA-level programme was organized together with Lincoln University from the United States.

The core of curricula at all levels is within social sciences and humanities, i.e. within economics and management as fields of academic expertise. This means that this constitutes the base for acquiring knowledge in these areas as applied to tourism. At the same time, taking into account the multidisciplinary nature of tourism, the curricula also include subjects from the following disciplines: Information Science, Quantitative Methods, Methodology of Scientific Research, Psychology, Geography and Spatial Planning and History of Art and Culture. In addition, emphasis is also placed on the learning 
of international languages at an advanced level for four years. The English language is intensively learned for four years at an advanced level with a view to application to the field of Tourism and Hospitality. One of the requirements of the entrance exam for undergraduate studies is an advanced level of use of the English language. Only the textbooks of Oxford and Cambridge universities are used, and there is a permanent cooperation with the British Council, which is also important for obtaining special certificates. In addition to the English language, students choose at least one of the following international languages, which are learned for four years: German, French, Russian, Spanish, Italian and Chinese. During the third and fourth year of undergraduate studies, students are required to do practical work for at least six months. Most of them do this part of their training in hotels, travel agencies and national and regional tourist organizations. In addition to the teachers, the realization of this programme requires employing experts from these companies and institutions. A sizable number of students who showed good results in their studies and practical work received scholarships, and a number of graduates obtained permanent employment. This constitutes one part of the well-implemented university practice for stimulating young talent and monitoring their professional development. This practice is also applied at the master and doctoral level. All $\mathrm{PhD}$ students are already employed in research and educational institutions or in the business sector. A number of them are also employed as regular associates of the University and this Faculty.

\section{REFERENCES}

Barrows, C. \& Bosselman, R. (1999). Hospitality Management Education. Haworth, Binghamton, NY.

Belhassen, Y. \& Caton, K. (2011). On the need for critical pedagogy in tourism education. Tourism Management, 32 (6), 1389-1396

Benckendorff, P. \& Zehrer, A. (Eds) (2015). International Handbook of Teaching and Learning in Tourism. Edward Elgar, Cheltenham.

Dredge, D. \& Schott, C. (2013). Academic agency and leadership in tourism higher education. Journal of Teaching in Travel \& Tourism, 13 (2), 105-129

Hsu, C., Xiao, H. \& Chen, N. (2017). Hospitality and tourism education research from 2005 to 2014: "Is the past a prologue to the future?" International Journal of Contemporary Hospitality Management, 29 (1), $141-160$

Inui, Y., Wheeler, D. \& Lankford, S. (2006). Rethinking tourism education: what should schools teach? Journal of Hospitality, Leisure, Sport \& Tourism Education, 5 (2), 25-35

Law, R. \& Chon, K. (2007). Evaluating research performance in tourism and hospitality. Tourism Management. 28 (5), 1203-1211

Munar, A. (2007). Is the Bologna process globalizing tourism education? Journal of Hospitality, Leisure, Sport \& Tourism Education. 6 (2), 68-82

Prebežac, D., Schott, C. \& Sheldon, P. (2014). The Tourism Education Futures Initiative. Routledge, Milton Park Sheldon, P. \& Hsu, C. (Eds) (2015). Tourism Education: Global Issues and Trends. Emerald, Bingley

Sheldon, P., Fesenmaier, D. \& Tribe, J. (2011). The Tourism Education Futures Initiative (TEFI): activating change in tourism education. Journal of Teaching in Travel \& Tourism. 11 (1), 2-23

Unković, S. (1990). Yugoslav Universities and Inter-University International Co-Operation. Higher Education in Europe. 15 (1), 8-11

Zagonari, F. (2009). Balancing tourism education and training. International Journal of Hospitality Management. $28(1), 2-9$ 


\section{RAZVOJ TALENATA I OBRAZOVNI SISTEM U OBLASTI TURIZMA}

\section{Rezime:}

I međunarodni i domaći turizam su postali jedan od najvažnijih faktora društvenog i privrednog razvoja u svetu. Iz tog razloga, kvalitetno obrazovanje u oblasti turizma, kao i unapređenje strategija za razvoj talenata trebalo bi da se smatraju pitanjima od najveće važnosti. U ovom radu izlažem svoj stav po pitanju osnovnog, srednjeg i visokog obrazovanja u oblasti turizma, kao i obrazovanja turističkih vodiča. Takođe ću predstaviti kratku studiju slučaja Univerziteta Singidunum, kao primera dobre prakse u visokom obrazovanju u oblasti turizma.

\section{Ključne reči:}

obrazovanje,

turizam i hotelijerstvo, visoko obrazovanje, srednje obrazovanje, stručno obrazovanje.

Received: November 3, 2017 Correction: /

Accepted: November 4, 2017 